\title{
SPIRITUALITY THROUGH THE IMAGES OF NATURE IN "NOVEMBER DAY AT MC CLURE'S"
}

\author{
Rio Febriannur Rachman \\ Airlangga University, Surabaya \\ riojaya21@gmail.com
}

\begin{abstract}
The analysis focuses on revealing spirituality through images of nature in Robert Bly's poem, "November Day at McClure's". The purpose of the study is to depict the kinds of images of nature used and the spirituality reflection in the poem. To complete the analysis, concept of nature classification by Coleman J. Goin and Oliver B. Goin is applied. Based on the concept, there are some groups of images of nature: landscape, phenomenon, animal, plant, object above the earth, and other nature object. The analysis result shows the images of nature in the poem consist of some kinds such as: landscape, animal, phenomenon, object above the earth, and other nature object. Based on the concept of Ary Ginanjar Agustian, there are some kinds of spiritual reflection: through messages of loving unconditionaly, awaring fate and God, responsibility, time perspective, and being free from material things. The analysis result shows that the spirituality can be reflected through the message of awaring fate and God and message of responsibility.
\end{abstract}

Keywords: spirituality; images; nature; poem

\section{INTRODUCTION}

Human reality consists of two opposing and irreducible elements: matter and mind, body and soul, or material and spiritual. The living person is one, as there is total unity and integration between the two distinctive expressions of reality, material and spiritual. The spirituality will guide human to be an integrated and unified human reality with some fundamental powers, they are: to know, to love, and to will. The sum up is spirituality will guide human to do anything on the way of rightness and peace (Danesh, 1994:18-19).

Human has to be aware that an aspect of life is the tension between the instinct, which is the property of the body, and the spiritual, which is the property of the soul or conciousness. Human civilization is the outcome of this interface, while human achievements and failures are the respective reflections of the victory of either the spiritual or the instinctual. For the spiritual to become victorious over the instinctual, for generosity to replace greed, and for love to overcome hate, one needs to learn to discipline the instinctual and animal-like appeties, to control the tendency toward violence and hostility, and to replace them with values of truth, unity and service (Danesh, 1994: 232).

From the first two paragraphs above, it can be taken one perception of how important the aspect of spirituality in human life is. Exploring that in everything, included in literary work 
is worthdoing. Knowing it through literary work, especially poem, will enrich the readers' knowledge and insight about spirituality.

Reaching spirituality can be done through several ways. Understanding the incredible of nature is one of them. Observing images of nature in literary work is also one of those ways. Nature is one aspect that can not be separated from human life. This consists of many wonderful and beautiful things which can open human's awareness about spirituality.

Robert Bly is one of the poets who really concerns with the theme of spirituality and nature. In 1995, Sierra Club Books located in San Fransisco, published a book which contains some poems which are choosen, written, introduced, and translated by Bly. The book named News of The Universe Poems of Two Fold Consciousness. The idiom 'Two Fold Conciousness' in the book's tittle refers to spirituality and nature. This proves that Bly really cares about those two things. One of the poems which is written in that book is "November Day at Mc Clure's" written in around 1974. The characteristic of spirituality in that poem is interesting to explore. It is reflected through the images of nature on some lines of the poem.

Leslie Ullman (2005) states that Bly often demonstrates spirituality in his criticism and his own poetry through the natural world, from silence and solitude, and it equips the reader to surface and fully confront the complexities of modern life. Those things can reflect how Bly is interested in spirituality and nature.

The ability of Bly in using images drives him to the circle of imagist poet. Ullman (2005) asserts that Robert Bly is one of the poets who can be classified into the group 'The Deep Image Movement of literature'. Bly's work, of course, enacts quite clearly the states of mind he calls for in American poetry. Many of his poems also echo the image construction and pacing of images in the poetry he has translated.

In Bly's other book, Silence in the Snowy Fields, published in 1962, most of the poems are drawn from the winter landscape of rural Minnesota, and the speaker of the poems reveals a brief, quiet, and joyful moment in a solitude and benevolent darkness. Those are the two elements Bly feels to have an important relation with the subconscious. Those evidents are some interesting points of Bly's creative world.

Thus, how important spirituality is, and how the nature can influence human life are choosen as the major topic of this analysis. This can be done by exploring the spirituality through observing the images of nature. The fact showing that Bly is the one who concerns about imagism, nature and spirituality used as the reason why using one of his poems, "November Day at Mc Clure's", as the object of analysis. 
According to the idea on the background of the study, the problems are formulated as follows: how images of nature employed in Robert Bly's "November Day at Mc Clure's"and how images of nature in "November Day at Mc Clure's" reflect spirituality. Those aim to reveal and describe the images of nature which reflect spirituality.

\section{REVIEW OF LITERATURE}

Through an unpublished undergraduate thesis from English Literature Department, State University of Surabaya, Rachman (2009), spirituality can be found in seven poems by Robert Bly. The conclusion of that research is not different from Ullman's (2005) statement few years before. It states that Robert Bly's poems sometimes show spirituality through certain ways.

Besides that, there are some researchers observe Robert Bly and his literary works. For example, Jeffery Alan Triggs through his article entitled Hurt into Poetry: The Political Verses of Seamus Heaney and Robert Bly and William A. Johnsen through article entitled Robert Bly, which it contains biography of that poet related to his literary works. Those prove that Robert Bly can be observed by multi perspective approach: spirituality, biography, political, etc.

The discussion will about two scopes. They are the employing images of nature to describe the subject or the meaning of images of nature themselves in "November Day at Mc Clure's" by combining the theory of image by White, Wafford, and Gordon (1967) and the concept of nature by Coleman J. Goin and Olive B. Goin (1970). Then, for describing the way spirituality reflects on the images of nature in the poem," the concept of spirituality by Ary Ginanjar Agustian (2007) is applied.

White, Wafford and Gordon (1967) state that poetic images may be divided into two kinds. First, the images which directly describe the subject. Second, the images which indirectly describe the subject by comparing them into something else which may have several similarities with the subject. In addition, if the subject is the image of nature, such as in the analysis of this study, that will describe the meaning of images of nature itself, whether directly or by comparing it to other similar things.

The study will use two basic concepts. They are the concept of nature and the concept of spirituality. The concept of nature is used to classify the image of nature in the poems into some groups. Based on the concept, images of nature in the poem will be classified into: 1) landscape, 2) animal, 3) plants, 4) object above the earth, and 5) the other nature objects. 
The concept of spirituality by Ary Ginanjar Agustian's (2007) will be used to analyze the way of images of nature reflects spirituality. The Images of nature may reflect spirituality through message of: 1) loving unconditionaly, 2) awaring fate and God, 3) responsibility, 4) time perspective, and 5) being free from material things.

\section{DISCUSSIONS OF THE MAIN THEME}

The discussion will be divided into three stages. First, the poem is paraphrased to express the message of the poem. Second, the analysis focuses on the images of nature, and the last, the discussion ends on the spirituality in the poem.

\subsection{The Poem}

\section{November Day at McClure's}

Alone on jagged rock at the south end of McClure's Beach.

The sky low. The sea grows more and more private, as afternoon goes on, the sky comes down closer, the unobserved water rushes out the horizon, horses galloping in a mountain valley at night. The waves smash up the rock; I find flags of seaweed high on the worn top, forty feet up, thrown up overnight, separated water still pooled there, like the black ducks that fly desolate, forlorn, and joyful over the seething swells, who never "feel pity for themselves," and "do not lie awake weeping for their sins." In their blood cells the vultures coast with furry next extended, watching over the desert for signs of life to end. It is not our life we need to weep for. Inside us there is some secret. We are following a narrow ledge aroeund a mountain, we are sailing on skeletall eerie craft over the bouyant ocean.

\subsection{Paraphrasing}

I stand alone on the jagged rock which is located in the south end of the McClure's beach. I see the waves of the sea move really lively. And the sea, it must be alone. It acts as looking something private as what I do now. Looking at the sea and feeling that sea is also alone and keeping its private as the afternoon comes into the day. The sky is very beautiful, meets the horizon, I think there are galloping horses on the valley in the evening. The waves smash the rock makes the seaweed flags on top of the water. The waves will smash all the night. Then I 
see the separated water of the sea. I reminds the desolated black ducks feel forlorn. The separated water is sheethed by the sweels. But they do not feel pity for themselves. And they do not weep for that reality. Then the vultures above the water look at the desert. May be there is sign of carrion that they can eat. I think this life is full of secret. Therefore, weeping is not needed. We are in the dynamic and not easy position. We are like following a narrow ledge around a mountain, we are sailing on skeletal eerie craft over the bouyant ocean.

\subsection{Images of Nature}

The poem uses free-verse style. It consists of only one stanza and fourteen lines. The images of nature spread on almost whole of the lines. There are only several lines which has no images of nature, they are in line six, eight, nine, and twelve.

Table 1. Images of Nature in Each Line

\begin{tabular}{ll}
\hline \multicolumn{1}{c}{ Line } & \multicolumn{1}{c}{ Images of Nature } \\
\hline One & Jagged rocked, the south end of McClure's Beach \\
\hline Two & Sky low, the sea \\
\hline Three & Afternoon, sky \\
\hline Four & The unobserved water, the horizon, horses, a mountain valley \\
\hline Five & Night, the waves, the rock, flags, seaweed \\
\hline Seven & Overnight, separated water, black ducks \\
\hline Ten & Blood cells, the vultures \\
\hline Eleven & The desert \\
\hline Thirteen & A narrow ledge around a mountain \\
\hline Fourteen & Skeletal eerie craft, bouyant ocean \\
\hline
\end{tabular}

Table 2. Images of Nature Group Classification

Group Images of Nature

Landscape Jagged rocked, the south end of McClure's Beach, the sea, the horizon, a mountain valley, the waves, the rock, the desert, bouyant ocean, skeletal eerie craft, a narrow ledge around a mountain

\begin{tabular}{ll}
\hline Animal & Horses, black ducks, the vultures \\
\hline Phenomenon & Afternoon, night, overnight \\
\hline Object above the earth & Sky low, sky \\
\hline Other nature objects & Seaweed, blood cells \\
\hline
\end{tabular}




\subsection{Spirituality}

\subsubsection{The image of Nature May Reflect Spirituality through Message of Being Aware about God}

The speaker of the poem tells the readers about the situation or the image around certain place which is called McClure's beach. He himself enjoys the loneliness on the jagged rock at the south end of McClure's beach by standing on the jagged rock, and finds that waves of the sea always smash the rock all night and everytime.

From the certain location, around McClure's beach, the speaker looks at the sea. He feels that the sea is alone as him. The sea, as a part of nature, has a private time. It has its own way in its own time. That is the law of nature such as the fate.

The speaker says that he stands on the jagged rock. Jagged rock is a rock that has some sharp and rough points. That may represent as human, now, life is hard and not an easy task to walk on. Some problems may come to human as the waves smash the rock. That has been a nature law. The rock in the shore will be smashed by waves until the surface not to be flat anymore. It seem like life which is never flat. It is always dynamic and fluctuative.

There is the water which is separated from the sea. It looks forlorn as the desolate ducks. In reality, sometimes on the beach, there is a puddle of water. Then sometimes the swell sheeths it. The vulture sometimes flies above the sea to find carrions for food. What happens in the puddle is the same as what has happened in the jagged rock. Those are the effects of the law of nature. Everything in the nature goes with the rule of fate. No complaining and interupting because nature has been predestined by something powerful that can be called God.

In some last lines of the poem, the speaker outlines that everyone does need to cry in every condition of life. Life can be described as the period among birth and death and every experience or state of being alive. Everyone can feel this period with his or her senses. Everyone can imagine the form of it by using his or her experiences. Whether in this period someone feels good or bad, has happy or sad experiences, the tear of weep is not useful for filling this period. That is what the speaker wants to say through the three last lines. 'It is not our life we need to weep for. Inside us there is some secret. We are following a narrow ledge aroeund a mountain, we are sailing on skeletall eerie craft over the bouyant ocean.'

The speaker also says that there is a secret in everyone's life. The secret is not known. If anyone knows about the secret, he or she can respond it as how he or she wants. In the sentence before, the speaker asks the readers not to weep. The speaker wants to remind the 
readers not to response the life by weeping, in order not to weep for secret thing that no one knows what it is.

The secret is a piece of information on life that is only known by some sides which are not a person or a creature. In someone's life, there is a big secret which he or she does not know, so the other ones certainly do not know either. The only one who is meant by the speaker is the powerful one and has authority to determine everyone's life. It can be called God. God determines the human's way of life.

\subsubsection{The Images of Nature May Reflect Spirituality through Message of Responsibility}

The speaker also says that 'everyone is following a narrow ledge around a mountain and sailing skeletal eerie craft over the bouyant ocean.' Based on the general experiences and perceptions, following a narrow a ledge mountain and sailing on skeletal eerie craft over the bouyant ocean are uncomfortable and enigmatic positioning and doing. The speaker wants to tell the readers that the life is not in a safe condition. Relating it with the early explanation about secret, the speaker also wants to tell that nobody knows about the final position of the tortuous life. So, no need to weep. It is better to do the best thing to walk on it. Everyone does not know about the secret, but everyone knows that he is on unsafe position. If everyone is on unsafe position of life, he is responsible to his own life because one has to be careful in the journey of life.

\section{CONCLUSION}

Robert Bly's "November Day at McClure's" contains some images of nature. The images can be classified into some certain groups such as: landscape, phenomenon, animal, object above the earth, and other natural objects. Some images of nature in the poem reflect spirituality through the message of awaring fate and God and message of responsibility.

Thus, not all of the kinds and groups of images of nature based on the concept of Coleman J. Goin and Olive B. Goin appear on the poem. Not all of spiritual reflections based on Ary Ginanjar Agustian's concept appear on the poem. Generally, the images of nature in "November Day at McClure's" can reflect spirituality. It also means that the poem explains some characteristics of spiritual people who have to possess the awareness of fate and God and also have to possess responsibility.

\section{REFERENCES}

Agustian, A. G. (2007). Emotional Spiritual Quotient. Jakarta: Arga Publishing. 
Bly, R. (1995). "November Day at McClure's". Bly, Robert (ed). News of the Universe Poems of Twofold Conciousness. San Fransisco: Sierra Club Books.

Danesh, H. B. (1994). The Psychology of Spirituality. Victoria: Paradigm Publishing.

Goin, C. J. \& Goin, O. B. (1970). Man and the Natural World. Toronto: Collier-Macmillan Canada, Ltd.

Rachman, R. F. 2009. Spirituality Through Images of Nature in Robert Bly'a Poems. Unpublished Undergraduate Thesis from English Literature Department: State University of Surabaya

Triggs, J. A. (1992). Hurt into Poetry: The Political Verses of Seamus Heaney and Robert Bly. Retrieved 7b April 2015 from rucore.libraries.rutgers.edu

Ullman, L. (2005).Deep Imagists: The Subconscious as Medium. Retrieved 7 April, 2015 from

http://www.google.co.id/url?sa=t\&rct=j\&q=\&esrc=s\&source=web\&cd=1\&cad=rja\&uact $=8 \&$ ved $=0 \mathrm{CBwQFjAA} \&$ url=http $\% 3 \mathrm{~A} \% 2 \mathrm{~F} \% 2 \mathrm{Fpersonal}$. colby. edu $\% 2 \mathrm{~F} \sim$ isadoff $\% 2 \mathrm{Fcap}$ \%2FUllman.doc\&ei=tbosVdPDJoG5mwWekYCwAg\&usg=AFQjCNH-

DPdsFKGYzB5J8Dm7Os6_U48Z_w\&bvm=bv.90790515,d.dGY.

White, E., Joan W., \& Gordon, E. J.(1967). Understanding Literature. Massachusetts: Gin and Co. 